обучения переводчиков-профессионалов / Е. Р. Поршнева // Психологическая наука и образование. - 2003. - № 1. - С.26-32. 7. Указ Президента України «Про заходи вдосконалення системи вищої освіти України»/ Міністерство освіти і науки України.№ 199/2004, 17.02. - Київ, 2004 8. Указ Президента України «Про Національну доктрину розвитку освіти» / Міністерство освіти і науки України. - №347/2002, 17.04. - Київ, 2002.

Юлія Лаптінова

\title{
ФОРМУВАННЯ ІНШОМОВНОЇ КОМУНІКАТИВНОЇ КОМПЕТЕНТНОСТІ МАЙБУТНІХ МУЗИКАНТІВ-ВИКОНАВЦІВ У ПРОЦЕСІ НАВЧАННЯ АНГЛІЙСЬКОГО ДІАЛОГІЧНОГО МОВЛЕННЯ
}

Лаптінова Ю. І. Формування іншомовної комунікативної компетентності майбутніх музикантів-виконавців у процесі навчання англійського діалогічного мовлення.

У статті запропоновано подальше розроблення теоретико-методичної концепції формування іншомовної комунікативної компетентності майбутніх фахівців у навчальному процесі вищого навчального закладу. 3'ясовано труднощі викладання іноземної мови на немовних спеціальностях 3 урахуванням специфіки музично-виконавської професійної діяльності. Розглянуто специфічні особливості діалогу як засобу становлення комунікативної компетентності майбутніх музикантів-виконавців. Запропоновано комплекс спеціальних вправ, на основі якого можна створити оптимальні умови для формування діалогічних умінь студентів.

Ключові слова: комунікативна компетентність, діалогічне мовлення, непрофілююча спеціальність, фахова підготовка.

Лаптинова Ю. И. Формирование иноязычной коммуникативной компетентности будущих музыкантов-исполнителей в процессе обучения английской диалогической речи.

В статье предложена дальнейшую разработку теоретико-методической концепции формирования иноязычной коммуникативной компетентности будущих специалистов в учебном процессе высшего учебного заведения. Выявлены сложности преподавания иностранного языка на неязыковых специальностях с учетом специфики музыкальноисполнительской профессиональной деятельности. Рассмотрены специфические особенности диалога как средства становления коммуникативной компетентности будущих музыкантов-исполнителей. Предложен комплекс специальных упражнений, на основе которого можно создать оптимальные условия для формирования диалогических умений студентов.

Ключевые слова: коммуникативная компетентность, диалогическая речь, непрофилирующая специальность, профессиональная подготовка.

Laptinova Yu. I. The formation of foreign language communicative competence of future musicians in teaching English dialogical speech.

The article suggests the further development of theoretical and methodological concept of foreign language communicative competence formation of future professionals in the educational process of universities.

There was revealed the complexity in teaching Foreign Language for students of nonlanguage specialties taking into account the specificity of musicians' professional activities. 
The article analyzes the specific features of dialogue as a means of formation of communicative competence of future musicians.

There was designed a set of special exercises which help to create the appropriate conditions for the formation of students' dialogical skills.

Key words: communicative competence, dialogical speech, non-major specialties, professional training.

Соціально-економічна ситуація, котра склалася нині, розкриває перед майбутніми спеціалістами нові можливості самореалізації, яка може здійснюватися через професійну діяльность в умовах іншомовного суспільства. Професійна діяльність музиканта-виконавця передбачає спілкування із зарубіжними колегами на міжнародному рівні. У цьому зв'язку, окрім високого професійного рівня володіння грунтовними знаннями 3 обраної спеціальності, сучасний фахівець мистецьких спеціальностей повинен вільно володіти однією або кількома іноземними мовами. Відтак першочерговим актуальним завданням освіти постає розвиток іншомовної комунікативної компетентності у студентів вищих навчальних закладах мистецького спрямування.

Іншомовна компетентність постійно знаходиться у фокусі уваги багатьох дослідників. Науковці А. Андриенко, Г. Архипова, Н. Бордовська, Н. Гез, С. Козак, І. Максимова, О. Павленко, Н. Пруднікова, Ю. Федоренко та інші розглядають іншомовну компетентність як багатоаспектне явище і висвітлюють його сутність і структуру.

Незважаючи на досить широкий діапазон існуючих досліджень, рівень розробленості проблеми формування комунікативної компетентності в галузі музичного виконавства 3 урахуванням специфіки музично-виконавської професійної діяльності залишається недостатнім. Окрім того, досвід роботи в музичному вищому навчальному закладі дав змогу зробити висновок про, загалом, досить низький показник рівня сформованості навичок професійно орієнтованого комунікативного спілкування, що свідчить про недостатньо ефективну організацію процесу мовної підготовки студентів музично-виконавських спеціальностей. Отже, суперечність між усвідомленням комунікативної компетентності як інтегративної основи фахової підготовки музиканта-виконавця і недостатнім фактичним рівнем оволодіння студентами комунікативними уміннями та навичками, необхідними для їх самореалізації в майбутньому професійному середовищі, визначила актуальність та доцільність удосконалення педагогічних технологій, спрямованих на створення умов для формування іншомовної комунікативної компетентності майбутніх музикантів-виконавців, зважаючи на специфіку навчального процесу мистецького вищого навчального закладу.

Mema cmammi - теоретично обгрунтувати наявні технологічні підходи до підвищення ефективності процесу формування іншомовної комунікативної компетентності майбутніх музикантів-виконавців у вищих навчальних закладах мистецького профілю та експериментально перевірити їх, визначити напрямки їх подальшого вдосконалення.

Відповідно до мети визначено такі завдання:

- уточнити ключові поняття дослідження («комунікативна компетентність» та «діалогічне мовлення») на основі теоретичного аналізу психолого-педагогічної літератури;

спеціальностях;

- охарактеризувати труднощі викладання іноземної мови на немовних

- виявити педагогічні можливості використання діалогу як засобу сприяння становленню комунікативної компетентності студентів мистецького профілю; 
- розробити і запропонувати комплекс спеціальних вправ та завдань, на основі якого можна створити оптимальні умови для формування діалогічних умінь студентів.

Професійна діяльність музиканта передбачає різноманітні ділові контакти за межами концертних залів Україні. Отже, успішність професійної діяльності майбутнього музиканта великою мірою залежить від рівня його мовно-комунікативної підготовки. Тому серед складників фахової підготовки майбутніх музикантів одну з найважливіших ролей відіграє комунікативна. Комунікативний критерій сформованості творчого потенціалу майбутніх музикантів-виконавців передбачає такі показники: уміння швидко й адекватно орієнтуватися в умовах колективної музичної взаємодії; контактність (інтеракція) взаємної перцепції в художньо-творчій діяльності; корекція власної діяльності у процесі комунікативної взаємодії [4]. Комунікативна компетенція розглядається В. Черниш як здатність здійснювати мовленнєву діяльність через реалізацію комунікативної, мовленнєвої поведінки на основі фонологічних, лексико-граматичних, соціологічних i країнознавчих знань та навичок відповідно до різноманітних завдань i ситуацій спілкування [8]. Комунікативна компетентність особистості- це вміння вільно, невимушено користуватися мовою у спілкуванні, тобто передавати й обмінюватися думками в різноманітних ситуаціях у процесі взаємодії з іншими учасниками, правильно використовувати систему мовленнєвих норм та вибирати комунікативну поведінку, адекватну автентичній ситуації спілкування [2]. Досліджуваний феномен комунікативної компетентності розглядається як динамічна інтегративна особистісна якість, яка визначає готовність і можливість творчої самореалізації в просторі соціального й професійного життя [5]. Отже, комунікативний складник фахової підготовки майбутніх музикантів означає оволодіння культурою діалогу, тобто взаємодію 3 іншими у процесі спілкування на засадах гуманістичних цінностей.

Для ефективного формування комунікативної компетентності в навчанні іноземних мов необхідно враховувати особливості навчання іноземної мови в мистецьких закладах. Можна зазначити низку труднощів, які ускладнюють формування високого рівня комунікативної компетентності студентів немовних спеціальностей:

1. Неоднаковий рівень підготовки студентів та їх володіння іноземною мовою під час вступу на немовні спеціальності вищого навчального закладу (розподіл студентів на групи за рівнем володіння мовою у практиці викладання іноземної мови не здійснюється).

2. Низький рівень мотивації студентів до вивчення іноземної мови, оскільки на багатьох немовних спеціальностях іноземна мова не $є$ профілюючим предметом.

3. Відсутність рекомендованого МОН України підручника для означеної категорії фахівців, що вимагає від педагогічних працівників значних додаткових зусиль, спрямованих на створення методичного забезпечення викладання предмета: добір та написання текстів іноземною мовою, складання вправ, виготовлення опорного матеріалу. Складність розроблення єдиного навчально-методичного комплексу для студентів, які неоднаково володіють іншомовними комунікативними компетентностями.

4. Надзвичайно малий термін для оволодіння професійною іншомовною комунікативною компетентністю студентами, які фактично змушені починати вивчення іноземної мови «з нуля» (при закладеному в навчальній програмі немовних спеціальностей навантаженні одна пара на тиждень - починаючи з другого курсу).

Зрозуміло, всі ці чотири проблеми тісно взаємопов'язані. Щоб зробити навчання іноземної мови на немовних спеціальностях ВНЗ більш ефективним і продуктивним необхідно тим чи тим способом розв'язати їх усі. 
Досвід викладання іноземної мови свідчить про те, що значна частина студентів (які часто опиняються в ситуаціях, коли вміння спілкуватися іноземною мовою $є$ особливо важливим), переконана, що така непрофілююча дисципліна, як іноземна мова не віддаляє, а наближає їх до оволодіння професійно важливими знаннями і навичками. Завдання викладача - скористатися позитивною мотивацією, а саме прагненням студентів до спілкування в конкретних професійних та ділових сферах. Опанувати комунікативною компетенцією, не перебуваючи в країні досліджуваної мови. За відсутності реальних умов професійної іншомовної комунікації великого значення набуває використання таких засобів навчання, які максимально можуть наблизити процес вивчення іноземної мови до ситуацій спілкування. Тому викладача повинен - створювати реальні та уявні ситуації ділового спілкування з використанням різних прийомів роботи. Діалог надає можливості створити максимально наближені до реальних ситуацій умови спілкування. Проблему навчання професійно орієнтованого діалогічного мовлення (ПОДМ) досліджують видатні українські та зарубіжні педагоги, психологи та методисти (П. Бех, Н. Гальскова, Л. Котлярова, О. Морська, С. Ніколаєва, Я. Окопна, Ю. Пассов, І. Чірва, С. Шатілов).

Діалог розглядається як ефективний дидактичний засіб накопичення, формування та розвитку суб'єктивних мовленнєвих знань, навичок і вмінь у процесі формування іншомовної професійно зорієнтованої комунікативної компетентності [1]. Діалогічне мовлення має комунікативні, психологічні і лінгвістичні особливості, а саме: воно складається 3 стимулюючих i реагуючих реплік; характеризується спрямованістю, спонтанністю, емоційністю й експресивністю [3]. Основними характеристиками професійно орієнтованого діалогу є: ініціативність, реакційність, виразність і спрямованість мовлення, логічний взаємозв'язок і взаємозумовленість реплік діалогу, спонтанність мовлення; відповідність комунікативного поводження ситуації і наміру партнера [7].

Застосування діалогічних ігрових ситуації під час аудиторних занять має великі можливості для формування комунікативної компетентності. Перевагою використання діалогової парної роботи в навчанні іноземної мови вважають створення емоційно комфортного й сприятливого для співпраці студентів мікроклімату. Це відбувається через те, що діалог - це найбільш природній вияв мовленнєвої активності, що базується на внутрішній мотивації мовця (тобто особистої потреби про щось сповістити або дізнатися). Діалог створює позитивний емоційний настрій студентів, оскільки в діалозі (у моделюванні природних актів комунікації) виникає цілковите задоволення від мовленнєвої діяльності. У процесі навчання англійської мови важливою є внутрішня (природна) мотивація, коли студент одержує задоволення від адекватної участі у професійно орієнтованої мовленнєвої діяльності. Професійна спрямованість завдань (ведення діалогу з фаху, обговорення проблем, пов'язаних з музичною специфікою) створює творче напруження, яке, стимулюючи студентів до активної мовленнєвої діяльності, наповнює позитивними емоціями. Саме в діалозі створюються умови для формування комунікативних умінь музикантів, необхідних для їх самореалізації в майбутньому професійному середовищі.

Реалізуються різні підходи до навчання діалогічного мовлення, 3 яких можна виокремити два основних. Відповідно до першого - «зверху вниз»- навчання розпочинається зі слухання діалогу-зразка 3 його наступним варіюванням, а згодом i створенням власних діалогів в аналогічних ситуаціях спілкування. Другий - «згори вниз»передбачає шлях від засвоєння спочатку елементів діалогу до самостійної побудови діалогу на основі запропонованої навчальної комунікативної ситуації, що не виключає прослуховування діалогів-зразків. 
Ми обрали перший шлях - «згори вниз» і виокремили такі рівні (етапи) формування діалогічних навичок i вмінь: перший (підготовчий) - навички імітування (уміння повторювати репліки і поєднувати готові репліки у діалог); другий - уміння будувати мікродіалоги 3 використанням різних типів наочності на основі запропонованих комунікативних ситуацій; третій - уміння створювати власні діалоги різних функціональних типів на основі запропонованих комунікативних ситуацій.

Для забезпечення ефективного розвитку навичок і вмінь діалогічного мовлення, необхідно застосовувати комплекс вправ. Згідно з визначеними етапами формування навичок і вмінь діалогічного мовлення студентів система вправ має містити 3 групи вправ:

-I група - вправи на імітацію. Формування діалогічного мовлення починається 3 першого (підготовчого) етапу, що передбачає прослуховування діалогу (тексту) -зразка. Мета вправ I групи - навчити учнів оперувати мовним матеріалом (зразками-виразами) у діалогічному мовленні шляхом імітування. На першому етапі студенти не продукують самостійних (ініціативних) реплік, лише повторюють і поєднують готові репліки в діалогічні єдності.

-II група- вправи на реплікування та реконструювання діалогу (наповнення й завершення діалогу) з використанням різних типів наочності. Мета вправ II групи - навчити учнів самостійно швидко й адекватно реагувати на подану репліку, продукувати ініціативну репліку, складати діалог «крок за кроком» за допомогою штучно створених або природних опор.

- III група - вправи на конструювання без використання різних типів опор. Мета вправ III групи - навчити учнів складати і вести власні діалоги в комунікативних ситуаціях, максимально наближених до умов реального спілкування. Не дозволяється використання опор. Студенти повинні вести бесіду без опори на зразок, використовуючи зміст прочитаного, брати участь у діалогах різних типів у межах програми мовного матеріалу. Учасниками спілкування є самі учні, а вчитель лише дає їм певне комунікативне завдання, де окреслюються ролі. Це так звані творчі вправи, в основу яких покладено засвоєну лексику і граматичні структури.

Поетапна методика розвитку діалогічного мовлення студентів перевірена экспериментально.

Отже ми дійшли висновку, що фахова підготовка студентів музичних спеціальностей мистецьких вищих навчальних закладів неможлива без формування іншомовної комунікативної компетентності. Під комунікативною компетентністю майбутнього музиканта-виконавця у сучасній науковій думці розуміється здатність реалізовувати усно мовленнєву комунікацію в цілеспрямованій музичній діяльності.

Теоретично обгрунтовано, що природна вмотивованість діалогічного спілкування у сфері професійної діяльності (професійно орієнтоване діалогічне мовлення) забезпечуватиме успішне формування комунікативної компетентності майбутніх музикантів-виконавців.

Розроблено, експериментально перевірено та впроваджено в педагогічну практику вправи для навчання діалогічного мовлення задля поетапного формування комунікативної компетентності у студентів мистецьких вищих навчальних закладів.

Система вправ складається 3 трьох етапів (рівнів формування діалогічних вмінь): вправи першого етапу спрямовані на засвоєння та оперування діалогічними єдностями; вправи другого етапу спрямовані на розвиток умінь студентів використовувати засвоєні ними види діалогічних єдностей для складання власних діалогів на основі опор; метою вправ третього етапу є розвиток навичок складати і вести самостійний діалог без допомоги будь- 
яких опор.

Зроблено висновок про перспективність упровадження в навчальний процес вищого музичного навчального закладу вправ на розвиток діалогічного мовлення, яке $\epsilon$ необхідною умовою формування професійних комунікативних умінь студентів музично-виконавських спеціальностей.

\section{Література}

1. Бакум 3. П. Етапи упровадження навчального діалогу в процесі вивчення іноземних мов майбутніми гірниками /3. П. Бакум, В. О. Лапіна // Педагогіка вищої та середньої школи : [зб. наук. праць]. - Кривий Ріг : Видавничий дім, 2014. - Вип. 41. - С. 84 85. 2. Безкоровайна О. В. Актуальні аспекти комунікативної компетенції студентів ВНЗ / О. В. Безкоровайна, Л. В. Мороз // Наукові записки Національного університету «Острозька академія». Сер. : Філологічна. - 2012. - Вип. 25. - С. 142- 145. 3. Берман И. М. Методика обучения английскому языку в неязыковых вузах / И. М. Берман. - Москва : Высшая школа, 1970. - 230 с. 4. Восводін В. В. Навчальний оркестровий колектив у становленні творчого потенціалу майбутнього музиканта-виконавця / Південноукраїнського державного педагогічного університету ім. К. Ушинського. - Одеса, 2007. - С. 12-19. 5. Мельник І. С. Інтерактивні технології навчання як засіб розвитку комунікативної компетентності студентів мовних ВНЗ / I. С. Мельник // Науковий вісник ПДПУ ім. К. Д. Ушинського. - 2008. - № 10-11， С. 285-294. 6. Пасинок В. Г. Мовна підготовка студентів як загальнопедагогічна проблема / В. Г. Пасинок; Харк. нац. ун-т ім. В. Н. Каразіна. - Харків, 1999. - 154 с. 7. Сура Н. А. Навчання студентів університету професійно орієнтованому спілкуванню іноземною мовою / Н. А. Сура. - Луганськ : Вид-во Східноукраїнського НУ ім. В. Даля, 2008. - 126 с. 8. Черниш В. В. Навчання іншомовного діалогічного мовлення в аспекті компетентнісного підходу / В. В. Черниш // Іноземні мови. Київ : Ленвіт - 2012. - № 4. - С. 11-27.

\section{Віктор Махінов}

\section{ОСОБЛИВОСТІ ВЗАЕМОДІЇ МОВИ І КУЛЬТУРИ В РОЗВИТКУ СОЦІКУЛЬТУРНОГО КОМПОНЕНТА ІНШОМОВНОЇ ОСВІТИ}

Махінов В. М. Особливості взаємодії мови і культури в розвитку соціокультурного компонента іншомовної освіти.

Актуальність дослідження зумовлена значущістю перспективи розвитку соціокультурного компонента в іншомовному освітньому просторі, соціокультурного чинника навчання іноземної мови для формування і розвитку особистості студентів педагогічних ВНЗ, для їх підготовки до професійного спілкування на міжкультурному рівні.

Ключові слова: соціокультурний компонент змісту навчання іноземної мови, соціокультурний аспект навчання іноземної мови, іншомовна комунікативна компетенція, міжкультурна комунікація, шкільна освіта, загальноєвропейський освітній простір.

Махинов В. М. Особенности взаимодействия языка и культуры в развитии социокультурного компонента иноязычного образования.

Актуальность исследования обусловлена значимостью перспективы развития социокультурного компонента в иноязычном образовательном пространстве, социокультурного фактора обучения иностранному языку для развития и формирования 